\title{
THROUGH THE GENDER LOOKING GLASS: FEMALE STUDENTS ATTITUDE TOWARDS ENTREPRENEURSHIP
}

\begin{abstract}
The purpose of the paper is firstly to identify the entrepreneurial attitudes of female Polish students from two universities and secondly to assess the contribution of these Polish universities in enhancing entrepreneurial attitudes amongst female students through entrepreneurship education and training programs. Paper questionnaires were used to survey students studying at Warsaw School of Economics and Rzeszow University of Technology. The respondents were undergraduate students participating in the general module of Management at Warsaw School of Economics and Statistics Methods at Rzeszow University of Technology. Participation in the survey was voluntary. The results reveal that $31 \%$ of the university female students were optimistic and interested in starting their own business, but only after gaining a few years of working experience which will enable them to deepen their knowledge and feel comfortable within a business environment. Only $8 \%$ of students would like to set up their own business immediately after graduation in comparison to menstudents where the level went up to $17 \%$. The study confirms that entrepreneurial education can positively reinforce student attitudes towards an entrepreneurial career choice within a developing country such as Poland. The research findings are of interest to academia and policy makers. The study suggests that entrepreneurial attitudes amongst Polish female students can be influenced by exposure to entrepreneurship education. Overall, the study indicates a need for entrepreneurship education, at programme and course levels, to nurture entrepreneurship among students in Poland. Very few studies have examined female students' attitude to entrepreneurship and entrepreneurship education in Poland. This study helps to bridge that gap.
\end{abstract}

Keywords: females, entrepreneurship, entrepreneurship education.

\section{INTRODUCTION}

A growing academic interest in entrepreneurship has developed alongside different economic changes, such as globalisation ${ }^{3}$ and the acceleration of technological deve-

\footnotetext{
${ }^{1}$ Dr Celina Sołek-Borowska, Instytut Zarządzania, Kolegium Zarządzania i Finansów, Szkoła Główna Handlowa, Warszawa; csolek@ sgh.waw.pl.

2 Dr Katarzyna Chudy-Laskowska, Katedra Metod Ilościowych, Wydział Zarządzania, Politechnika Rzeszowska im. Ignacego Łukasiewicza, Al. Powstańców Warszawy 10, 35-959 Rzeszów.

${ }^{3}$ E. Gummesson, Relationship marketing in the new economy, ,Journal of Relationship Marketing”, Vol. 1, No. 1, 2002, pp. 37-58.
} 
lopment ${ }^{4}$. This has led to rapid improvements in the competitive environment ${ }^{5}$ with organisations desperately needing to adapt to these changes and develop innovative products, services, processes, and business models ${ }^{6}$.

The demand for including enterprise and entrepreneurship studies in the education system, at all levels, has gained much attention from academia and societies all over the world. This prolonged and heightened interest in entrepreneurship is prompted by several factors. First, for developed economies, entrepreneurial activity (new venture formation) is a means of revitalizing stagnated economies and of coping with unemployment problems by providing new job opportunities. Moreover, entrepreneurship is a great force for economic growth, recovery and societal progress in terms of employment, social empowerment and innovation ${ }^{7}$. However, it has a more critical role for economies of developing countries since entrepreneurship is seen as an engine of economic progress, job creation and social adjustment. Thus, small business growth/new business formation is widely encouraged by national economic policies to stimulate economic growth and wealth creation.

The traditional role of educators - that of producing good employees - has been challenged by those seeking to encourage and support enterprise culture, particularly for students who aim to work for themselves and employ others ${ }^{8}$. Although many universities in the world offer courses on entrepreneurship, little evidence is available about students taking these courses and their intentions to become entrepreneurs ${ }^{9}$. Roxas et al. $(2008)^{10}$ claim that knowledge gained from formal entrepreneurship education programmes will boost individual entrepreneurial intentions. The idea of the entrepreneurial university has recently entered into the debate ${ }^{11}$. It is argued that a country's development and economic growth can be achieved by promotion of enterprise education among students a trait that requires knowledge of entrepreneurship, financial resources and the business environ-

${ }^{4}$ M. Santoro and A. K. Chakrabarti, Firm size and technology centrality in industry-university interactions, „Research Policy”, Vol. 31, 2003, pp. 1163-1180.

5 J.A. Siguaw, T.L. Bakes and P.M. Simpson, Preliminary evidence on the composition of relational exchange and its outcomes: the distributor perspective, „Journal of Business Research”, Vol. 56, 2003, pp. 311-22.

${ }^{6}$ L. Szerb, The changing role of entrepreneur and entrepreneurship in network organisations, Knowledge Transfer, Small and Medium-Sized Enterprises, and Regional Development in Hungary, JATE Press, Hungary, 2003, pp. 81-95, K. Lengyel (Trans.).

7 B.A Soomro, N. Shah, Developing attitudes and intentions among potential entrepreneurs. "Journal of Enterprise Information Management", Vol. 28, Issue 2, 2015, pp. 304-322.

${ }^{8} \mathrm{~T}$. Clawson, UK Universities gear up for enterprise education, www.forbes. com/sites/trevorclawson/2014/12/16/uk-universities-gear-up-for-enterprise-education/ (access: 15 December 2014).

9 A. Basu and M. Virick, Assessing entrepreneurial intentions amongst students: a comparative study, 2008, www.researchgate.net/publication/255583956_Assessing_Entrepreneurial_Intentions_Amongst_Students_A_Comparative_Study (access: 21 January 2016).

10 B.G. Roxas, R. Cayoca-Panizales, Entrepreneurial knowledge and its effects on entrepreneurial intentions: development of a conceptual framework. "Asia-Pacific Social Science Review", Vol. 8 No. 20, 2008, pp. 61-77.

${ }_{11}$ P. McGowan, P. Sijde, D. Kirby, The role of universities in the entrepreneurship industry: promoting the entrepreneurship agenda in HEIs. "Industry and Higher Education", Vol. 22 No. 1, 2008, pp. 49-59. 
ment ${ }^{12}$. The review by Gorman et al. $(1997)^{13}$ indicates that by aligning education with entrepreneurship, countries lacking resources and employment opportunities can foster entrepreneurial attributes, and the potential of students, which in turn could bring several economic benefits. The aims of this research are twofold. Firstly, to identify the entrepreneurial attitudes of Polish students, and secondly to determine the role of Polish higher education institutions in cultivating an entrepreneurial attitude amongst students through entrepreneurship education and training.

To this end two institutions were studied: the Warsaw School of Economics (SGH) and Rzeszow University of Technology (PRZ). The remainder of this study is structured as follows. Section 2 reviews the literature on the state of entrepreneurship in Poland, followed by the development of research questions, research design and methodology in section 3. The empirical results and discussion of the findings are presented in section 4.

\section{THEORETICAL BACKGROUND}

\subsection{State of art in entrepreneurship}

As research on entrepreneurship shows, there is no universal definition or concept of entrepreneurship in existing organizations ${ }^{14}$. Instead, the concept is rich with different approaches and assumptions. Therefore there is no single construct of entrepreneurship, which results in different operationalizations of this concept ${ }^{15}$.

Research literature reveals entrepreneurship as a socioeconomic force, a state of mind in the business economy which can generate employment opportunities, particularly new businesses, via intuitive ability, instincts, unique values, attitudes and skills ${ }^{16}$. The impact of entrepreneurship is always seen as positive in the economy.

With the increasing expansion of the European Union it is essential that member states network and share their expertise and talent. In 2004, Poland and nine post-communist states became an integral element of the European Union ${ }^{17}$. Countries such as Poland offer several advantages for business including a competitively priced and educated workforce,

${ }^{12}$ P. Milius, J. Sarkiene, Entrepreneurship training for innovative start-ups: the KTC case, in van der Sijde, P., Annemarie Ridder, A., Blaauw, G. and Diensberg, C. (Eds), Teaching Entrepreneurship, 2008, ISBN 978-3-7908-2038-6, Physica-Verlag HD, Heidelberg, pp. 23-33.

${ }^{13}$ G. Gorman, D. Hanlon, W. King, Some research perspectives on entrepreneurship education, enterprise education and education for small business management: a ten-year literature review. "International Small Business Journal", Vol. 15 No. 3, 1997, pp. 56- 77.

${ }^{14}$ P. Davidsson, Research Entrepreneurship. Springer, New York; Idem: The Domain of Entrepreneurship Research: Some Suggestions. In: „Advances in Entrepreneurship, Firm Emergence and Growth", 2005, Ed. J.A. Katz.

$15 \mathrm{~W}$. Dyduch, Corporate entrepreneurship measurement for improving organizational performance, ,Journal of Economics and Management”, Vol. 4, 2008, pp. 15-40.

${ }^{16}$ Z.J Acs, M.I. Megyesi, Creativity and industrial cities: a case study of Baltimore, "Entrepreneurship and Regional Development: An International Journal”, Vol. 21 No. 4, 2009, pp. 421-439; A. Azhar, A. Javaid, M. Rehman, A. Hyder, Entrepreneurial intentions among business students in Pakistan. "Journal of Business Systems, Governance and Ethics", Vol. 5 No. 2, 2010, pp. 13-21; V. Johansen, T. Schanke, T. H. Clausen, "Entrepreneurship education and pupils: attitudes towards entrepreneurs", 2010, available at: www.intechopen.com (access: 11 August 2013).

17 A.M. Nikodemska-Wołowik, Family enterprises - a chance to create a strong Polish identity. “The Marketing Review", Vol. 6 No. 4, 2006, pp. 301-15. 
proximity to the centre of the EU and a huge indigenous market ${ }^{18}$. Since the collapse of communism in Eastern European countries, expectations were raised within the population of improved standards of living ${ }^{19}$.

Poland has historically faced high unemployment (18.2\% in 2005, the highest in the EU), corruption, excessive bureaucracy and migration of skilled workers to other EU member states, issues which remain ongoing concerns ${ }^{20}$. The ongoing decline of the public sector controlled coal mining industry has caused further problems in the Upper Silesia region which has been criticised for its lack of entrepreneurial activity, although benefiting from EU assistance ${ }^{21}$. There have, however, been some major improvements ${ }^{22}$. For example, Poland has benefited from significant foreign investment from major manufacturing companies including Fiat, Hewlett Packard, Toyota, Cadbury, Dell and Sharp ${ }^{23}$ aiming to capitalise on the lower operating costs. Moreover, Waters ${ }^{24}$ (1999) notes that there has been significant growth within the retail service sector driven by the introduction of multinational companies such as Tesco, Unilever, Jeronimo Martin Dystrybucja, to name just a few. Currently the unemployment rate is $7.7 \%$.

Due to the dynamic nature of the Polish labour market university graduates have found themselves in a relatively difficult situation. Today, youth unemployment is already 28.2\% (Central Statistical Office in Poland 2017) and there is little evidence on the possibility of improving this situation. Extending the retirement age has caused a blockage of many jobs in the next few years, so graduates frequently have no chance to replace older workers. In addition, the market is saturated with specialists in various industries and professions, resulting in a lack of jobs for people with similar qualifications who do not have professional experience. The consequence of the lack of employment opportunities for young people is to look for other types of income. The best opportunity for graduates seems to be setting up their own business. Many young graduates, perceiving little chance of finding good and forward-looking work commensurate with their education and ambitions, decide to set up their own business. According to the Central Statistical Office, onethird of currently operating Polish companies are run by people who are under 30 years of age. Despite all the difficulties and concerns, more and more people decide to start their career in their own company. According to research conducted by the Foundation for

18 J.T. Por, J. White, An entrepreneur's guide to Eastern Europe. European Business Review, Vol. 94, No. 3, 1991, pp. 33-43.

19 P. Foley, J. Hutchinson, A. Kondej, J. Mueller, Economic development in Poland: a local perspective. "European Business Review", Vol. 96, No. 2, 1996, pp. 23-31, http://dx.doi.org/ 10.1108/09555349610111839; J. Reichal and A. Rudnicka, Collaboration of NGOs and business in Poland. "Social Enterprise Journal", Vol. 5, No. 2, 2009, pp. 126-40.

${ }^{20} \mathrm{D}$. Smallbone, F. Welter, The role of government in SME development in transition economies, "International Small Business Journal", Vol. 19 No. 4, 2001, pp. 63-77.

${ }^{21}$ G. Blazyca, K. Heffner, E. Helinska-Hughes, Poland - can regional policy meet the challenge of regional problems? "European Urban and Regional Studies", Vol. 9, No. 3,2002, pp. 263-76.

${ }^{22}$ M. Kostera, Differing managerial responses to change in Poland. "Organization Studies", Vol. 16, No. 4, 1995, pp. 673-97.

${ }^{23}$ P. Foley, J. Hutchinson, A. Kondej, J. Mueller, Economic development in Poland: a local perspective. "European Business Review", Vol. 96, No. 2, 1996, pp. 23-31.

${ }^{24} \mathrm{C}$. Waters, Changing the role of the retail sector in Poland during a period of economic transition. "International Journal of Retail \& Distribution Management", Vol. 27 No. 8, 1999, pp. 319-27. 
Initium, as many as $78 \%$ of students would like to start their own company, and $4 \%$ already are the owners of them ${ }^{25}$.

\subsection{Entrepreneurship education}

Entrepreneurial education is perceived as one of the most important challenges of modern educational systems and socio-economic development. Although entrepreneurial education is currently a hot topic in the literature on entrepreneurship worldwide, it is only an emerging subject in Poland, although it is increasingly undertaken by researchers in various fields ${ }^{26}$.

According to Reynolds et al. (1999) ${ }^{27}$ appropriate education and training programs in entrepreneurship are expected to increase the number of people becoming entrepreneurs because the better educated the population the higher the level of entrepreneurial activity. There has been a notable expansion in the number of entrepreneurship programmes globally in recent times ${ }^{28}$, although participation does not always lead to nascent entrepreneurship $^{29}$. This has often been driven by the belief that education is best placed to equip students with the necessary knowledge and skills required to prosper in working environments $^{30}$. In terms of the entrepreneurial experience however, there is ongoing debate regarding the essential attitudes towards education components of an effective entrepreneurship education programme ${ }^{31}$. Indeed, Anderson and Jack $(2008)^{32}$ argue that entrepreneurship education is a difficult area to lecture on due to its variability, complexity and contingency.

The authors consider entrepreneurship education as an important part of managerial education. Entrepreneurial competencies are not limited to those that aim to set up a new business venture. On the contrary, they are important to managers, specialists or almost any employee working in contemporary, changing organizations. Entrepreneurial means

${ }^{25}$ W. Chmielniak, Raport społeczny: przedsiębiorczość studentów i absolwentów (Social report: Entrepreneurship of students and graduates), www.youngpro.pl/artykuly/sposob-na-kariere/raport-spoleczny-przedsiebiorczosc-studentow-i-absolwentow (access: 10.07.2017)

${ }^{26} \mathrm{~K}$. Wach, Edukacja przedsiębiorcza: analiza bibliometryczna polskiego piśmiennictwa (Entrepreneurship: bibliometric analysis of Polish literature). "Horyzonty Wychowania", Vol. 15, No. 34, 2016, pp. 11-26.

${ }^{27}$ P. D. Reynolds, M. Hay, S.M. Camp, Global Entrepreneurship Monitor: 1999 Executive Report, Kauffman Centre for Entrepreneurial Leadership at the Ewing Marion Kauffman Foundation, Kansas City, 1999, MO.

28 J. Katz, Chronology and intellectual trajectory of American entrepreneurship education 1876-1999. "Journal of Business Venturing", Vol. 18, No. 2, 2003, pp. 283-300.

${ }_{29}^{2}$ D.F. Kuratko, The emergence of entrepreneurship education: development, trends and challenges. "Entrepreneurship Theory and Practice", Vol. 29, No. 5, 2005, pp. 577-97; H. Matlay, C. Carey, Entrepreneurship education in the UK: a longitudinal perspective. "Journal of Small Business Enterprise and Development", Vol. 14, No. 2, 2007, pp. 252-63.

${ }^{30}$ A. Adcroft, S. Dhaliwa, R. Willis, Insatiable demand or academic supply: the intellectual context of entrepreneurship education. "European Business Review", Vol. 17, No. 6, 2005, pp. 518-31.

${ }^{31}$ L. Pittaway, J. Cope, Entrepreneurship education: a systematic review of the evidence. Working Paper Series No. 2, National Council for Graduate Entrepreneurship, Birmingham, 2006, pp. 1-33.

32 A. Anderson and S. Jack, Role typologies for enterprising education: the professional artisan?. "Journal of Small Business and Enterprise Development", Vol. 15, No. 2, 2008, pp. 259-73. 
being innovative, forward looking for opportunities, undertaking new initiatives. Those people with such skills are destined to work for any type of business.

Business and management school graduates are expected to possess appropriate knowledge, skills and social competencies. Some of them will become managers, company owners and should help to guide us through the turbulent world of modern organizations $^{33}$.

Studying business seems to be fashionable and needed. Representatives of different jobs like doctors, farmers and painters decide to study business to help move forward through difficult and challenging economic times. Entrepreneurship education is needed in any kind of profession, as no one knows at which stage of life they will become an entrepreneur.

\subsection{Women entrepreneurship}

The past 30 years have seen significant changes in the status and political weight of women entrepreneurs, as well as a rapid increase of interest and research on the topic. In fact, starting with the first papers in the early 1970s, research on female entrepreneurship has expanded to a variety of disciplines, methods and countries ${ }^{34}$.

By the end of the 1990s, the field of female entrepreneurship was established as a well-respected and defined area of academic inquiry and female entrepreneurship had become a popular argument for the media and for political debates on employment and labour markets. In addition to women entrepreneurs' professional characteristics and achievements, research has been conducted on issues related to health, motherhood, family position and life style satisfaction ${ }^{35}$.

In general, interest in female entrepreneurship in developing countries has significantly increased. This is owing to at least two related reasons. First, it is due in part to the general increase in interest for the role of entrepreneurship in the economic development process $^{36}$.

The second reason for the rise of interest in female entrepreneurship in developing countries is owing to the rapid increase in the number and proportion of female entrepreneurs in the developing world ${ }^{37}$ and the insight that female-led micro- and small enterprises (MSEs) can have a more significant impact on overall household welfare and consumption than male-led MSEs.

Female entrepreneurship contributes to economic development by creating new products and jobs. The growing number of women who are owners of companies proves that women exhibit entrepreneurial features that allow them to effectively overcome social barriers and actively participate in economic processes. The highest rate of growth of

${ }^{33}$ M. Kostera, Differing..., pp. 673-97.

${ }^{34}$ M. Minniti, W. Naudeé, What Do We Know About The Patterns and Determinants of Female Entrepreneurship Across Countries? „The European Journal of development Research“, Vol. 22, Issue 3, 2010, pp. 277-293.

${ }^{35}$ M. Schindehutte, M. Morris and C. Brennan, Entrepreneurs and motherhood: Impacts on their children in South Africa and the United States, Journal of Small Business Management 41 (1), 2003, p. 94-107.

36 T. Gries and W.A. Naudé, Entrepreneurship and structural economic transformation „Small Business Economics Journal” 34 (1), 2010, p. 13-29.

${ }^{37}$ M. Kevane, and B. Wydick, Microenterprise lending to female entrepreneurs: Sacrificing economic growth for poverty alleviation? „World Development” 29 (7), 2001, p. 1225-1236. 
companies founded by women in Poland could be observed in the first years of transformation, when feminised plants were closed and women lost their jobs en masse. During the entire transformation period, relatively more self-employed women than men came. According to OECD data showing the share of self-employed women among all employed, Poland has been at the top of this category for years. Also in Europe alone, the female entrepreneurship rate in Poland (including the self-employed rate) has remained one of the highest for years. In the light of the literature on the subject, the high activity of Polish women in the sphere of entrepreneurship is significantly influenced by both the "push" factor (the sense of responsibility for the family's economic existence) and the factor of "attraction", especially for young, well-educated women, associated with highincome business search and self-realization ${ }^{38}$. At the same time, women are more likely than men to undertake a business activity due to the lack of other sensible alternatives and not the will to seize the opportunity. It is important for them to have the motivation to set up their own company, such as: striving for independence and independence in deciding on their own fate; striving to achieve higher income and gain financial independence; the possibility of professional development; negative experience from wage labor and favorable market conditions.

\section{RESEARCH METHODOLOGY}

The research was undertaken at Warsaw School of Economics and Rzeszow University of Technology in the summer semester of May 2016. The students at both Universities were asked to complete a paper questionnaire about entrepreneurship. Students were assured of anonymity in the reported results and could withdraw their participation at any time. As a pilot, an online version of the questionnaire was sent first to five students and five other teachers to check whether the questions are properly understood and to check validity.

\subsection{Warsaw School of Economics}

Warsaw School of Economics is considered to be one of the best business-oriented universities in Poland. It is known for its connections with businesses, and associations to international organizations. There is a very strong link with businesses that is visible through courses run by academic teachers and managers from companies. Moreover student organisations are very active in organising events like the Marathon of consulting firms or exhibition days. Students aim to create a platform of communication between the best students and market leaders, and they highlight that international corporations are the best places to start their business career ${ }^{39}$. In such situations the issue of starting their own business seems to be put under a question mark. "What career path should I follow...?" seems to be an interesting question for both SGH and Rzeszow University students.

The presence at SGH of global companies like McKinsey, Procter and Gamble, L'Oréal Polska, Deloitte or Ernst and Young is a confirmation of the high level of teaching and high calibre of students. Companies have the opportunity to engage with potential employees and students can acquaint themselves with the business world. The relationship is beneficial to both parties.

\footnotetext{
${ }^{38}$ Report, Przedsiębiorczość kobiet w Polsce (Women entrepreneurship in Poland), PARP, 2011.

${ }^{39}$ Exhibition leaflet, Exhibition of FMCG, prepared by the Students' Association at SGH.
} 


\subsection{Rzeszow University of Technology}

Rzeszow University of Technology, located in the south-eastern part of Poland, is amongst the best technical universities in Poland. The Management Faculty was created in 1993 in response to increased demand for management education. The business links are well established with Aviation Valley, which supports automotive and aviation provision companies.

The Business Council was created in 2012 on the initiative of the Dean's office, with associate business leaders operating mainly in Podkarpackie Province. The main goal of the Council is the formation of a platform to advise on creating high quality scholarly achievements, modernization of teaching processes, activation of business contacts and initiating promotional and marketing activity. It is the task of the Business Council to improve the exchange of experience between academic teachers and practitioners of management. The latest initiative was the world entrepreneurship week organized in November in 2017.

\subsection{Sample}

227 female students took part in the research out of 566 students. 152 female students represent Warsaw School of Economics and 125 female students represent Rzeszow University of Technology. The majority of respondents had an average of grade 4 and above (51\%). Most of them were first year students (73\% of the study group). The "other" option includes third-year students and masters students. The most-represented discipline is Quantitative methods and Information Systems (32\%), Finanace (25\%) and Logistics $(14 \%)$. Other disciplines include economics, e-business, econometrics, computer science and data analysis.

Table 1. Characteristic of the sample

\begin{tabular}{|l|l|c|c|}
\hline & & Sample size & Percentage \\
\hline \multirow{3}{*}{ Place } & Rzeszow & 125 & $55 \%$ \\
& Warsaw & 152 & $45 \%$ \\
\hline \multirow{5}{*}{ Average grade } & from 3.0 up to 3.49 & 8 & $3 \%$ \\
& from 3.5 up to 3.99 & 76 & $28 \%$ \\
& from 4.0 up to 4.4 & 137 & $51 \%$ \\
& from 4.5 up to 5.0 & 48 & $18 \%$ \\
\hline \multirow{5}{*}{ Discipline/ } & Finance & 68 & $25 \%$ \\
& Management & 28 & $10 \%$ \\
& International relations & 86 & $32 \%$ \\
& Logistics & 37 & $14 \%$ \\
& Quantitative methods and & 25 & $9 \%$ \\
& information systems & & $10 \%$ \\
\hline \multirow{3}{*}{ Year of study } & Other & 28 & $73 \%$ \\
& 1st year & 201 & $21 \%$ \\
& 2nd year & 57 & $7 \%$ \\
\hline
\end{tabular}

Source: Own development. 
The research questions are as follows:

1. What are the attitudes of female students (of both Universities) towards entrepreneurship? (i.e. are they interested in setting up their own businesses after graduation?)

2. Does the university education of students influence their attitude towards entrepreneurship?

3. What kind of activities are femal students undertaking to enhance their entrepreneurial attitudes?

The null and alternative hypotheses are as follows:

$\mathrm{H}^{0}$ - entrepreneurial attitudes of female and men students are quite similar

$\mathrm{H}^{1}$ - entrepreneurial attitudes of female and men students are different

It is recognized that, whilst there is a body of literature on entrepreneurial intentions and attitudes, there is a lack of research devoted to gender differences in undertaking entrepreneurial activity and the current paper adds to this body of literature and makes a significant contribution to the research on factors influencing entrepreneurial attitudes among female students. Moreover, the investigated role of the Universities in shaping entrepreneurship education offers a new perspective.

\section{RESEARCH FINDINGS}

According to Safin $^{40}$ there is a conviction in Polish society that a successful career of a young person is related to finding interesting work in a large company, rather than the establishment of his own company. Such a view is influenced not only by the recent past, in which the company was a rather marginal and often forced undertaking, but also a contemporary assessment of the professional prestige of the entrepreneur. According to the "Rzeczpospolita" daily rankings, the entrepreneur is in a distant position. Although a relatively high-value entrepreneur enjoys a high reputation (but it is relatively rare to find a wealthy entrepreneur), small entrepreneurs, who account for $90 \%$ of all companies in Poland, enjoy the same status as a person without a profession.

\subsection{Female students attitude to set up a business}

In order to select the entrepreneurially inclined students, the question "what are you planning to do after graduation?" was asked. The results are presented in Figure 1. It is not surprising that $31 \%$ of female students responded that after obtaining a few year of work experience they plan to open their own business. On the other hand $33 \%$ of men would do so. Students consider working for a company as a possibility of gaining the experience and expertise necessary to set up their own business. The greatest difference concerning plans aftre graduation exist in terms of seeting one's own company. Only $8 \%$ of female students consider setting up their own business just after graduation in comparison to men where $17 \%$ would do so.

It can be stated that gender influences enterpreneurial attitudes. The differences are significant concerning plans after graduation $\mathrm{p}<\alpha(\mathrm{p}=0,00172)$ therefore $\mathrm{H}^{0}$ hypothesis is rejected for the benefit of $\mathrm{H}^{1}$ hypothesis.

${ }^{40}$ K. Safin, Przedsiębiorcze zachowania studentów - stan i konsekwencje dla dydaktyki (Entrepreneurship of students - the current state and the consequences for didactics), "Horyzonty Wychowania", Vol. 13, No. 26, 2014, pp. 327-340. 


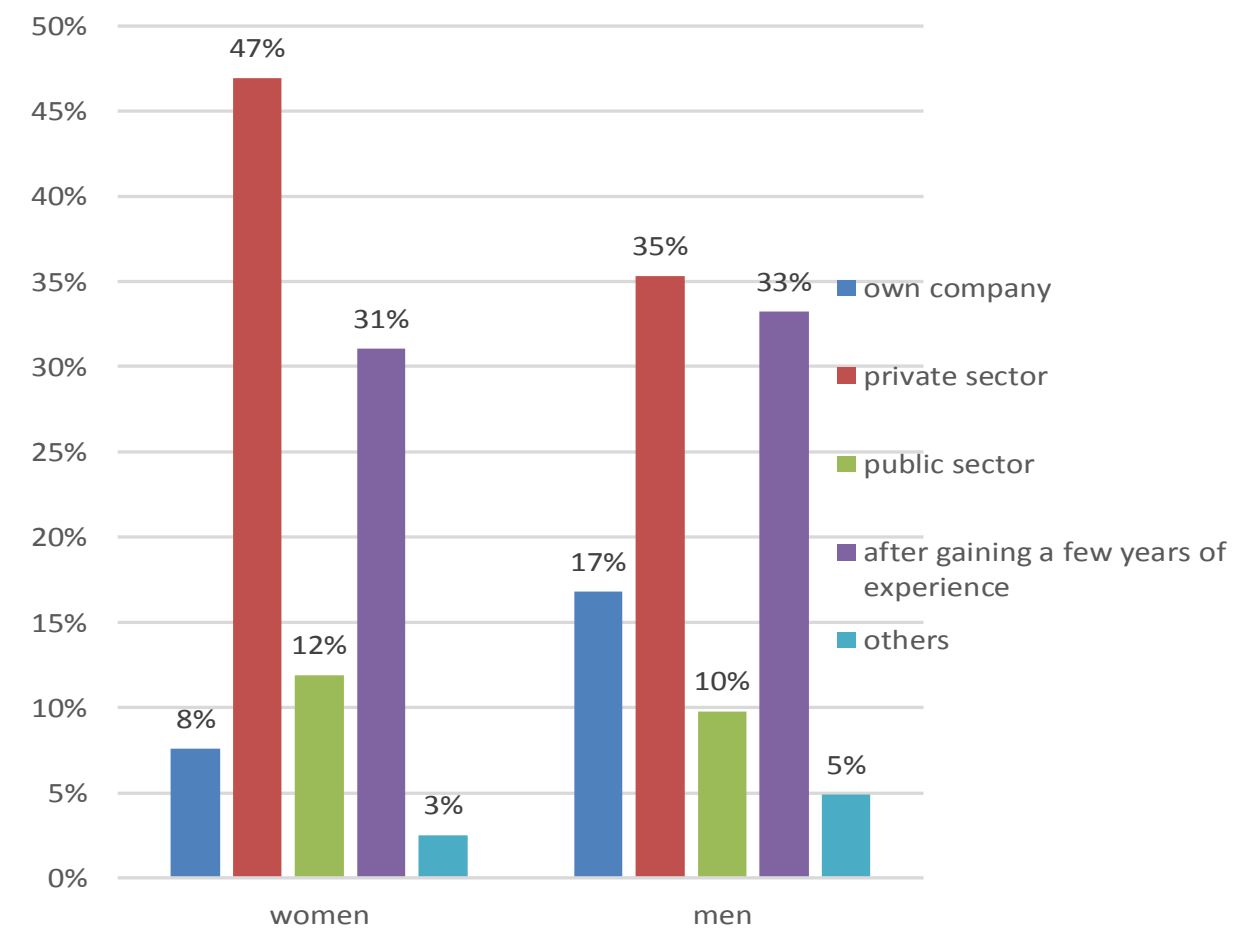

Figure 1. Employment plans after graduation concerning gender

Source: Own development, $\mathrm{n}=277$ woman, $\mathrm{n}=286$ men

Although much has been accomplished in the field of female entrepreneurship, it is clear that, far from being exhausted, the field lends itself to a variety of extensions and further investigations especially concerning the risk aversion and reasons to undertake the enterpreneurial ventures.

\subsection{Students' education in entrepreneurship}

Education is one of the factors that stimulate entrepreneurship, especially in terms of fostering entrepreneurial awareness ${ }^{41}$. The idea is that how entrepreneurship attitudes can be developed which is actually related with the mindset of individuals.

Programs that support entrepreneurship through financial grants, training and internships do not appear to deliver the expected results and end their lives at the end of the required period. One of the main reasons is the ineffective education process in this context as noted by $\operatorname{Safin}^{42}$ (2014).

The view on whether entrepreneurship can be learned differs in the group of women and men. Men are more often convinced that entrepreneurship can be learned (this is what almost half of men admit 47\%) more often they also think that entrepreneurship can not

${ }^{41}$ K. Wach, Edukacja..., 2016, pp. 11-26.

${ }^{42}$ K. Safin, Przedsiębiorcze..., pp. 327-340. 
be learned (2\%). In the group of women it was less than $1 \%$ of the respondents and this is presented in Figure 2.

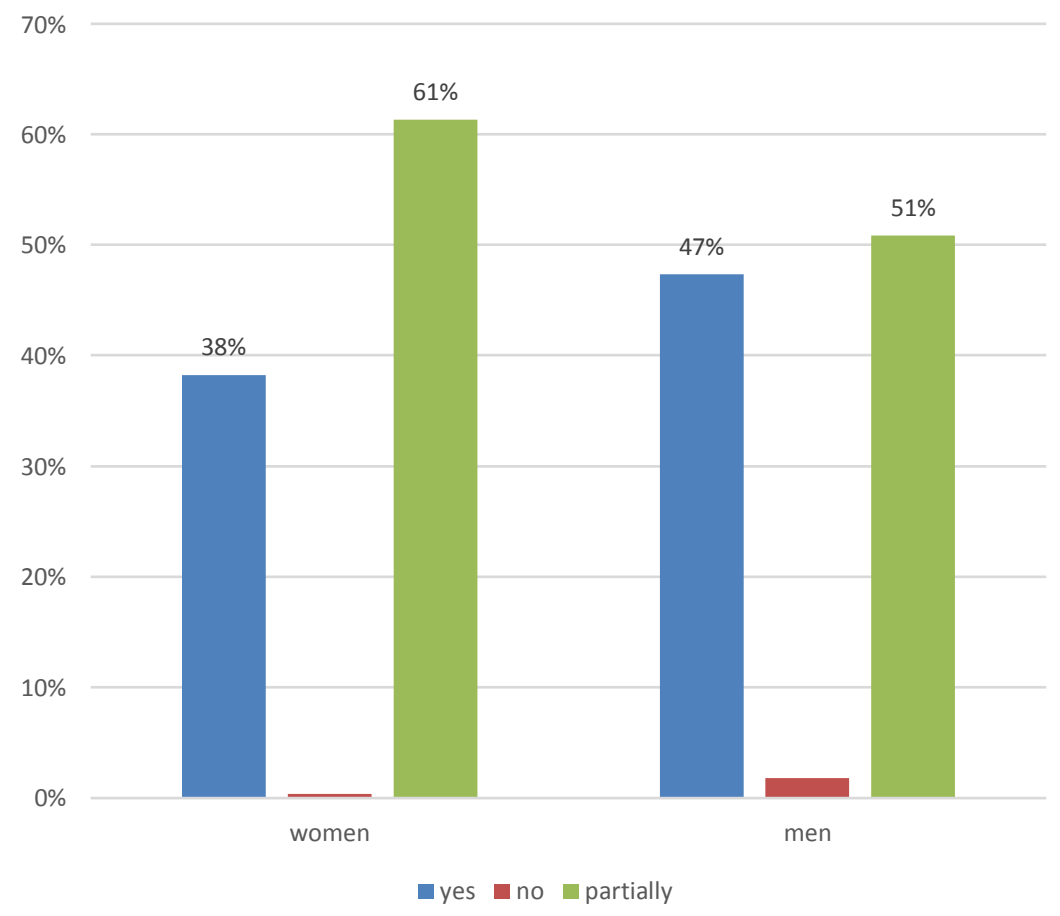

Figure 2. Entrepreneurship and education comparison on men and women

Source: Own development, $\mathrm{n}=566$

Students were also asked whether the education you are gaining at university by participating in different modules enhances your entrepreneurship skills? Students could select from 1 - I strongly disagree to 5 - I strongly agree using the Likert scale. The results are presented in Figure 3.

$11 \%$ of female students strongly agree, and $64 \%$ of female students partially agree that the education they are gaining at university enhanced their entrepreneurial attitude, confirming the role of the university in shaping this attitude. This is strong evidence that there is an important place for academic teachers to include entrepreneurial studies in education and is in line with the view of Wach, Jiménez-Moreno and Wach who state that education, and in particular teaching entrepreneurship, shapes the entrepreneurial attitude and entrepreneurship intentions (Wach 2013, 2015; Jiménez-Moreno \& Wach 2014) ${ }^{43}$.

${ }^{43}$ K. Wach, Edukacja..., pp. 11-26; K. Wach, Środowisko..., pp. 25-40; J.J. Jiménez-Moreno, $\mathrm{K}$. Wach, The entrepreneurial profile of students. Participating in the Academic Entrepreneurship Course: Pilot Study Results, "Horyzonty Wychowania" 2014, Vol. 13, No. 26, pp. 121-143. 


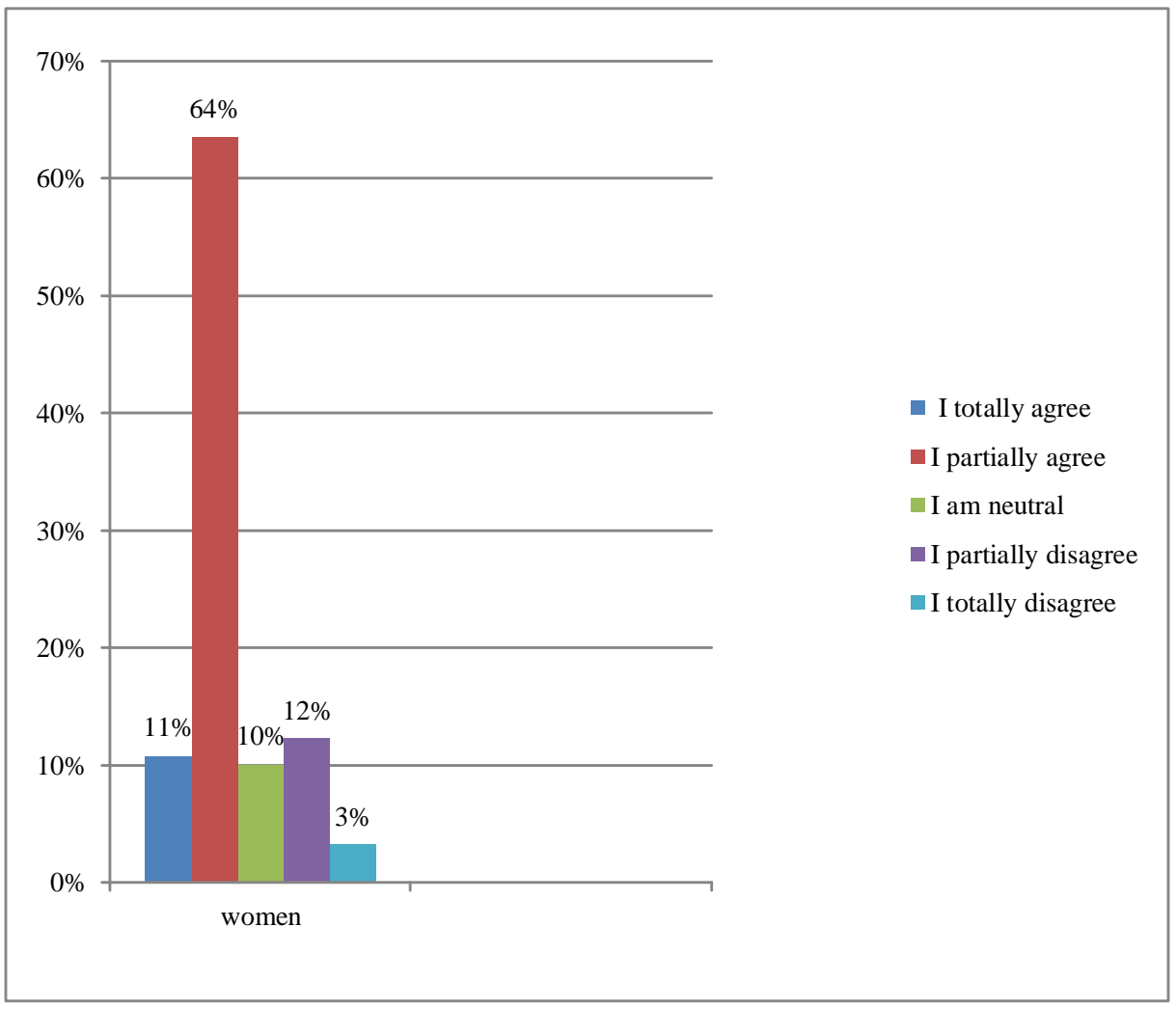

Figure 3. Education and women entrepreneurship

Source: Own development, $\mathrm{n}=277$

\subsection{Students' activities forming entrepreneurial attitudes}

In creating an entrepreneurial attitude it is important to know one's predispositions and talents and to create opportunities to develop them during didactic or individual work. Such attitudes can be developed at school, in the local community or in the home environment. It is of particular importance to create situations in which a young person can become acquainted with themselves, in order to find their future place in changing social and professional structures ${ }^{44}$ (Zioło 2012).

The question: "how do I enhance my entrepreneurial attitude" is meant to analyse what steps female students undertake to develop their entrepreneurial attitude. The question was not obligatory and meant to be answered only by entrepreneurially inclined students, but all students answered this, which confirms that students from both Universities regard entrepreneurship in a wider aspect and even though some want to work for someone else they still want to develop their entrepreneurial attitude. Students were able to tick as many

${ }^{44}$ Z. Zioło, Miejsce przedsiębiorczości w edukacji (Place of the entrepreneurship in education). "Przedsiębiorczość - Edukacja", Vol. 8, 2012, pp. 10-23. 
answers as were relevant to them. The most popular answer was: "I regularly surf the Internet" which was expressed by $65 \%$ of female students. Female students are also using the Internet, especially social media like Youtube, to learn about success stories of startups. The second option was circled by $25 \%$ of students, who participated in conferences. $22 \%$ of students were inclined to read books, articles, and success stories of entrepreneurs. $16 \%$ of students helped family members or a relative to run a company. These responses are presented in Figure 3. Some students are also involved in students projects that deal with problems concerning the setting up of a business.

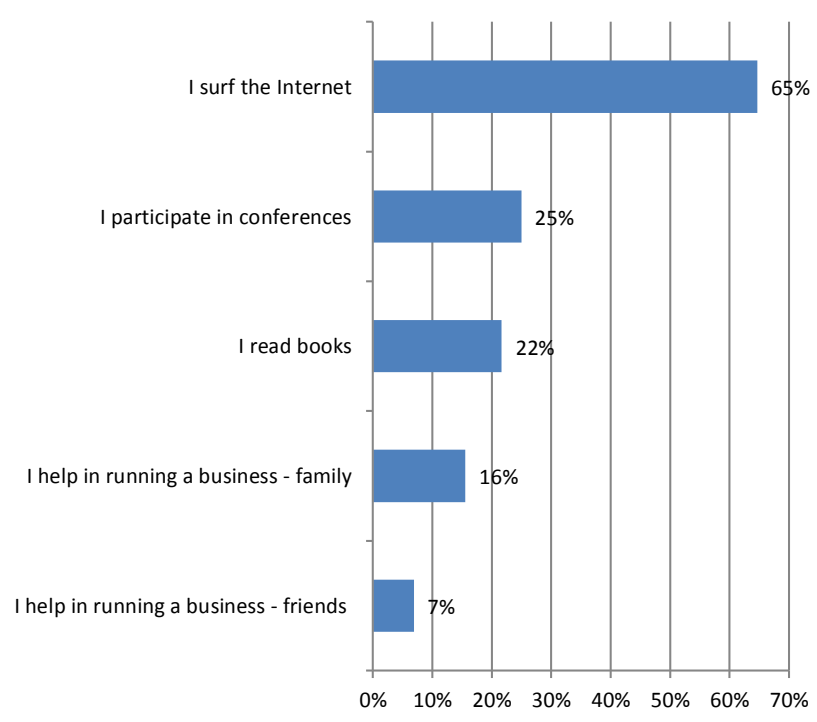

Figure 3. Ways of developing entrepreneurial attitude

Source: Own development, $\mathrm{n}=266$

These kind of activities belong to informal entrepreneurship education. The impact of informal education on entrepreneurship can be recognized as one of the fundamental factors that help students to understand and foster an entrepreneurial attitude.

\section{CONCLUSIONS}

Entrepreneurs are recognized as important drivers of economic and social progress, and entrepreneurial initiatives for young people are regarded as an important factor in the future growth of a nation. Consequently, universities are expected to play a major role in propagating an entrepreneurial attitude among students and graduates and nurturing future entrepreneurs. This explains why a growing number of universities start to offer specialized entrepreneurship courses and programs in their business curriculum.

The aim of this study is to investigate female students' attitudes to setting up their own business, focusing on the cases of the Warsaw School of Economics and Rzeszow University of Technology and the role of the university in developing enterprise education in Poland. 
To sum up, it can be stated that entrepreneurial attitudes amongst Polish female students is not high for both groups of students, although there is a switch towards setting up a business after gaining a few years of work experience. This is also confirmed by Slovic $(2000)^{45}$ who posits that "(A)lmost every study of risk perception has found that men seem to be less concerned about hazards than are women." Chung (1998) ${ }^{46}$ agrees, arguing that "both the marketing and psychological literature suggest than men tend to make more risky judgements than women."

However, the study observes that university, by establishing effective connections with global business, can help students by providing such exposure and could be the right place to impart enterprise education.

By providing the necessary knowledge in the teaching system and the distinction in the attitude of teaching entrepreneurship education in relation to young people entering the labor market. Attention should be paid to the individualisation of educational paths of girls and women in order to equalize their chances on the labor market and to move away from the stereotype of women's professions in order to raise interest in the professions of the future. There should also be a greater emphasis on career counseling at the stage of the last grades of junior high school schools. Programs such as "Girls at Technical Universities" and promoting women in the roles of employers, managers and business owners are desirable.

Actions to change stereotypes in the perception of women's and men's roles and shaping family relations require the promotion of a partner family model and dissemination of positive examples in school curricula and activities of educational and upbringing programs, in the activities of educational and cultural-educational institutions and the media.

The research results are part of a bigger research project that aims to investigate entrepreneurial attitudes of students in Thailand, UK, USA and Canada. This study provides compelling evidence that students want to start their entrepreneurial activity after gaining a few years of work experience. It would be inappropriate to generalize these results to actual entrepreneurial behaviours until such a relationship is confirmed by other empirical research. Also the findings are not universally applicable to any country as the education system needs to be analysed beforehand.

Our results are based solely on the self-evaluation of students, regarding their capability and awareness about starting a new business venture. This could have a strong impact on their perceptions and intentions. Further research could investigate whether the students have over-estimated or under-estimated their proficiency, and the extent to which the self-evaluations reflect their actual skills and the consequent impact on entrepreneurial ability

\section{REFERENCES}

[1] Acs Z.J., Megyesi M.I., Creativity and industrial cities: a case study of Baltimore, "Entrepreneurship and Regional Development: An International Journal”, Vol. 21, No. 4, 2009, pp. 421-439.

\footnotetext{
${ }^{45}$ P. Slovic, The Perception of Risk, Earthscan Publications Ltd, London, 2000.

46 J.T. Chung, Risk reduction in public accounting firms: are women more effective?, "International Review of Women and Leadership", Vol. 4, No. 1, 1998, pp. 39-45.
} 
[2] Adcroft A., Dhaliwal S., Willis R., Insatiable demand or academic supply: the intellectual context of entrepreneurship education, "European Business Review", Vol. 17, No. 6, 2005, pp. 518-31.

[3] Anderson A. and Jack S., Role typologies for enterprising education: the professional artisan?, "Journal of Small Business and Enterprise Development", Vol. 15, No. 2, 2008, pp. 259-73, http://dx.doi.org/10.1108/14626000810871664.

[4] Azhar A., Javaid A., Rehman M., Hyder A., Entrepreneurial intentions among business students in Pakistan, "Journal of Business Systems, Governance and Ethics", Vol. 5 No. 2, 2010, pp. 13-21.

[5] Baldassarri S., Saavala T., Entrepreneurship - educating the next generation of entrepreneurs, "Enterprise Europe", Vol. 22, July, 2006, pp. 16-20.

[6] Basu A. and Virick M., Assessing entrepreneurial intentions amongst students: a comparative study, 2008, www.researchgate.net/publication/255583956_Assessing_Entrepreneurial_Intentions_Amongst_Students_A_Comparative_Study (access: 21 January 2016).

[7] Blazyca G., Heffner K., Helinska-Hughes E., Poland - can regional policy meet the challenge of regional problems?, "European Urban and Regional Studies", Vol. 9 No. 3,2002, pp. 263-76.

[8] Chmielniak W., Raport spoteczny: przedsiębiorczość studentów i absolwentów (Social report: Entrepreneurship of students and graduates), 2013, www.youngpro.pl/artykuly/sposob-na-kariere/raport-spoleczny-przedsiebiorczosc-studentow-i-absolwentow (access: 10.07.2017).

[9] Chung J.T., Risk reduction in public accounting firms: are women more effective?, "International Review of Women and Leadership", Vol. 4, No. 1, 1998, pp. 39-45.

[10] Clawson T., UK Universities gear up for enterprise education, 2014, www.forbes. $\mathrm{com} /$ sites/trevorclawson/2014/12/16/uk-universities-gear-up-for-enterprise-education/ (access: 15 December 2014).

[11] Davidsson P., The Domain of Entrepreneurship Research: Some Suggestions. In: „Advances in Entrepreneurship, Firm Emergence and Growth”. Ed. J.A. Katz, 2005.

[12] Dyduch W., Corporate entrepreneurship measurement for improving organizational performance, ,Journal of Economics and Management”, Vol. 4, 2008, pp. 15-40.

[13] Foley P., Hutchinson J., Kondej A., Mueller J., Economic development in Poland: a local perspective, "European Business Review", Vol. 96, No. 2, 1996, pp. 23-31, http://dx.doi.org/10.1108/09555349610111839.

[14] Gorman G., Hanlon D., King W., Some research perspectives on entrepreneurship education, enterprise education and education for small business management: a ten-year literature review. "International Small Business Journal", Vol. 15, No. 3, 1997, pp. 56-77, http://dx.doi.org/10.1177/0266242697153004.

[15] Gries T. and Naudé W.A., Entrepreneurship and structural economic transformation, „Small Business Economics Journal” 34 (1), 2010, pp. 13-29.

[16] Gummesson E., Relationship marketing in the new economy, „Journal of Relationship Marketing", Vol. 1, No. 1, 2002, pp. 37-58.

[17] Jack S.L., Anderson A.R., Entrepreneurship education within the enterprise culture, "International Journal of Entrepreneurial Behaviour \& Research", Vol. 5, No. 3, 1999, pp. 110-25, http://dx.doi.org/10.1108/13552559910284074.

[18] Jiménez-Moreno J.J., Wach K., The entrepreneurial profile of students. Participating in the Academic Entrepreneurship Course: Pilot Study Results, "Horyzonty Wychowania", Vol. 13 No. 26, 2014, pp. 121-143. 
[19] Johansen V., Schanke T., Clausen T.H., Entrepreneurship education and pupils: attitudes towards entrepreneurs, 2012, available at: www.intechopen.com (access: 11 August 2013).

[20] Katz J., Chronology and intellectual trajectory of American entrepreneurship education 1876-1999, "Journal of Business Venturing", Vol. 18, No. 2, 2003, pp. 283-300.

[21] Kevane M. and Wydick B., Microenterprise lending to female entrepreneurs: Sacrificing economic growth for poverty alleviation?, „World Development” 29 (7), 2001, pp. 1225$-1236$.

[22] Kierulff H.E., Entrepreneurship in Poland: findings from the field, "Human Factors and Ergonomics in Manufacturing", Vol. 15 No. 1, 2005, pp. 93-8.

[23] Kostera M., Differing managerial responses to change in Poland, "Organization Studies", Vol. 16, No. 4, 1995, pp. 673-97.

[24] Kuratko D.F., The emergence of entrepreneurship education: development, trends and challenges. "Entrepreneurship Theory and Practice", Vol. 29, No. 5, 2005, pp. 577-97, http://dx.doi.org/10.1111/j.1540-6520.2005.00099.

[25] Matlay H., Carey C., Entrepreneurship education in the UK: a longitudinal perspective. "Journal of Small Business Enterprise and Development", Vol. 14 No. 2, 2007, pp. 252-63, http://dx.doi.org/10.1108/14626000710746682.

[26] McGowan P., Sijde P., Kirby D., The role of universities in the entrepreneurship industry: promoting the entrepreneurship agenda in HEIs, "Industry and Higher Education", Vol. 22, No. 1, 2008, pp. 49-59, http://dx.doi.org/10.5367/ 000000008783876986.

[27] Milius P., Sarkiene J., Entrepreneurship training for innovative start-ups: the KTC case, in van der Sijde P., Annemarie Ridder A., Blaauw G. and Diensberg C. (Eds), Teaching Entrepreneurship, ISBN 978-3-7908-2038-6, Physica-Verlag HD, Heidelberg, 2008, pp. 23-33, http://dx.doi.org/10.1007/978-3-7908-2038-6_4.

[28] Minniti M., Naudeé W., What Do We Know About The Patterns and Determinants of Female Entrepreneurship Across Countries? „The European Journal of development Research“, Vol. 22, Issue 3, 2010, pp. 277-293.

[29] Mueller S.L. and Thomas A.S., Culture and entrepreneurial potential: a nine country study of locus of control and innovativeness, "Journal of Business Venturing" 2000, Vol. 16, pp. 51-75, http://dx.doi.org/10.1016/S0883-9026(99)00039-7.

[30] Nikodemska-Wołowik A.M., Family enterprises - a chance to create a strong Polish identity, "The Marketing Review", Vol. 6, No. 4, 2006, pp. 301-15.

[31] Pittaway L., Cope J., Entrepreneurship education: a systematic review of the evidence, Working Paper Series No. 2, National Council for Graduate Entrepreneurship, Birmingham, 2006, pp. 1-33, http://dx.doi.org/10.1177/0266242607080656.

[32] Por J.T., White J., An entrepreneur's guide to Eastern Europe, European Business Review, Vol. 94, No. 3, 1991, pp. 33-43.

[33] Reichal J., Rudnicka A., Collaboration of NGOs and business in Poland, "Social Enterprise Journal", Vol. 5, No. 2, 2009, pp. 126-40, http://dx.doi.org/ 10.1108/ 17508610910981716.

[34] Raport, Przedsiębiorczość kobiet w Polsce (Women entrepreneurship in Poland, 2011, PARP, 2011.

[35] Reynolds P.D., Hay M., Camp S.M., Global Entrepreneurship Monitor: 1999 Executive Report, Kauffman Centre for Entrepreneurial Leadership at the Ewing Marion Kauffman Foundation, Kansas City, MO, 1999. 
[36] Roxas B.G., Cayoca-Panizales R., de Jesus R., Entrepreneurial knowledge and its effects on entrepreneurial intentions: development of a conceptual framework, "Asia-Pacific Social Science Review", Vol. 8 No. 20, 2008, pp. 61-77, http://dx.doi.org/10.3860/ apssr.v8i2.784.

[37] Safin K., Przedsiębiorcze zachowania studentów - stan i konsekwencje dla dydaktyki (Entrepreneurship of students - the current state and the consequences for didactics), "Horyzonty Wychowania", Vol. 13, No. 26, 2014, pp. 327-340.

[38] Santoro M. and Chakrabarti A.K., Firm size and technology centrality in industryuniversity interactions, „Research Policy”, Vol. 31, 2003, pp. 1163-80.

[39] Schindehutte M., Morris M. and Brennan C., Entrepreneurs and motherhood: Impacts on their children in South Africa and the United States, "Journal of Small Business Management" 41 (1), 2003, pp. 94-107.

[40] Siguaw J.A., Bakes T.L. and Simpson P.M., Preliminary evidence on the composition of relational exchange and its outcomes: the distributor perspective, „Journal of Business Research", Vol. 56, 2003, pp. 311-22.

[41] Smallbone D., Welter F., The role of government in SME development in transition economies, "International Small Business Journal", Vol. 19, No. 4, 2001, pp. 63-77, http://dx.doi.org/10.1177/0266242601194004.

[42] Slovic P., The Perception of Risk, Earthscan Publications Ltd, London 2000.

[43] Socha M., Weisberg J., Labour market transition in Poland - changes in the public and private sectors, "International Journal of Manpower", Vol. 23, No. 6, 2002, pp. 553-77.

[44] Soomro B.A., Shah N., Developing attitudes and intentions among potential entrepreneurs, "Journal of Enterprise Information Management", Vol. 28, Issue 2, 2015, pp. 304-322, http://dx.doi.org/10.1108/JEIM-07-2014-0070.

[45] Szerb L., The changing role of entrepreneur and entrepreneurship in network organisations, Knowledge Transfer, Small and Medium-Sized Enterprises, and Regional Development in Hungary, JATE Press, Hungary, 2003, pp. 81-95, K. Lengyel (Trans.).

[46] Wach K., Edukacja przedsiębiorcza: analiza bibliometryczna polskiego piśmiennictwa (Entrepreneurship: bibliometric analysis of Polish literature), "Horyzonty Wychowania", Vol. 15, No. 34, 2016, pp. 11-26, http://doi: 10.17399/ HW.2016.153401.

[47] Wach K., Środowisko biznesu rodzinnego jako stymulanta intencji przedsiębiorczych młodzieży akademickiej (The family business environment as a stimulant for the entrepreneurial intentions of the academic youth), "Przedsiębiorczość i Zarządzanie", XVI (7(III)), 2015, pp. 25-40.

[48] Waters C., Changing the role of the retail sector in Poland during a period of economic transition, "International Journal of Retail \& Distribution Management", Vol. 27, No. 8, 1999, pp. 319-27.

[49] Węcławska D., Zadura-Lichota P., Wpływ edukacji na postawy przedsiębiorcze i przygotowanie młodych Polaków do prowadzenia dziatalności gospodarczej (The impact of education on entrepreneurial attitudes and preparation of young Poles to do business). In: A. Wilmańska (ed.) Raport o stanie sektora małych i średnich przedsiębiorstw w Polsce w latach 2008-2009 (Report on the state of small and medium enterprises in Poland in 2008-2009), 2010.

[50] Williams D.R., Effects of childcare activities on the duration of self-employment in Europe, „Entrepreneurship Theory and Practice” 28 (5), 2004, pp. 467-485.

[51] Zioło Z., Miejsce przedsiębiorczości w edukacji (Place of the entrepreneurship in education), "Przedsiębiorczość - Edukacja", Vol. 8, 2012, pp. 10-23. 
PRYZMAT PLCI: STOSUNEK KOBIET DO PRZEDSIĘBIORCZOŚCI

Celem artykułu jest identyfikacja postaw przedsiębiorczych polskich studentów - kobiet z dwóch uczelni oraz ocena wkładu polskich uczelni w poprawę postaw przedsiębiorczych wśród studentów poprzez oferowanie programów kształcenia w zakresie przedsiębiorczości. W badaniu postaw studentów - kobiet, zostały zostały wykorzystane ankiety. Studenci reprezentowali dwie uczelnie wyższe: Szkołę Główną Handlową w Warszawie oraz Politechnikę Rzeszowską. Respondentami byli studenci studiów licencjackich uczęszczający na przedmiot: „Zarządzanie“ Szkoły Głównej Handlowej oraz przedmiotu: Metody Statystyczne na Politechnice Rzeszowskiej. Udział w ankiecie był dobrowolny. Wyniki pokazują, że $31 \%$ kobiet było zainteresowanych rozpoczęciem własnej działalności gospodarczej, ale dopiero po zdobyciu kilkunastoletniego doświadczenia zawodowego, które pozwoli im pogłębić wiedzę i poczuć się komfortowo w środowisku biznesowym. Tylko 8\% kobiet chciałoby założyć własną firmę natychmiast po ukończeniu studiów, podczas gdy $17 \%$ mężczyzn rozpoczęłoby pracę na własny rozrachunek. Badanie potwierdza, że kształcenie w zakresie przedsiębiorczości może pozytywnie wzmocnić postawy przedsiębiorcze wobec wyboru kariery zawodowej w kraju rozwijającym się, takim jak Polska. Wyniki badań są interesujące dla środowisk akademickich i decydentów. Badanie sugeruje, że postawy przedsiębiorcze wśród polskich studentek mogą wpływać na na kształcenie w zakresie przedsiębiorczości. Ponadto, badanie wskazuje na potrzebę kształcenia w zakresie przedsiębiorczości, na poziomie programów i kursów, w celu wspierania przedsiębiorczości wśród studentów - kobiet w Polsce. Istnieje znikomy procent badań dotyczący przedsiębiorczości kobiet i edukacji w zakresie przedsiębiorczości w Polsce. Badanie to pomaga wypełnić lukę badawczą.

Słowa kluczowe: kobiety, przedsiębiorczość, edukacja przedsiębiorcza.

DOI: $10.7862 /$ rz.2017.mmr.36

Tekst złożono $w$ redakcji: grudzień 2017 r.

Przyjęto do druku: grudzień 2017 r. 